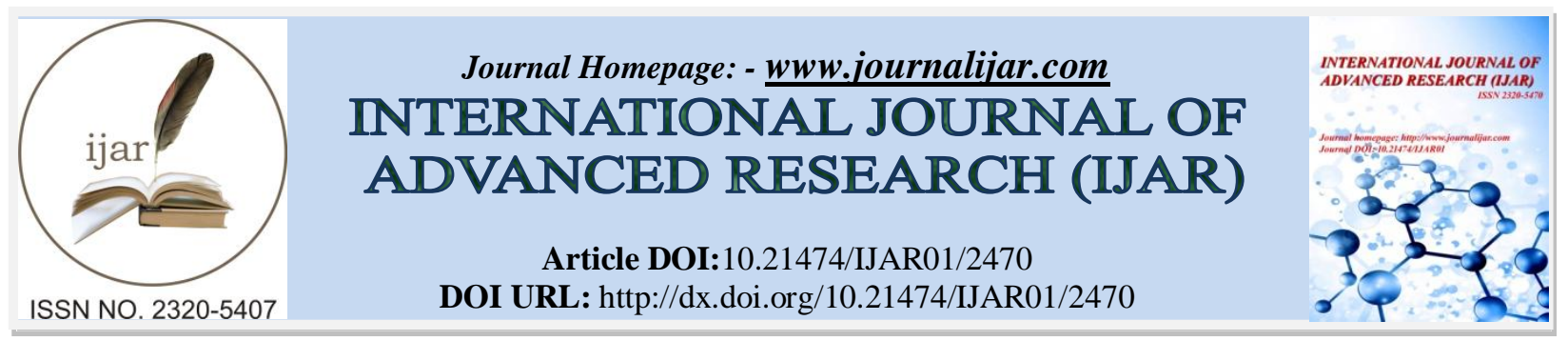

RESEARCH ARTICLE

\title{
TOWARDS A MORE APPROPRIATE\& WATER EFFICIENT STREETSCAPE DESIGN.
}

\author{
Hadia Mohamed Fathy Mohamed Saad ${ }^{1}$, Basil Ahmed Kamel Phd ${ }^{2}$ and Karim ElGhazali Kesseiba ${ }^{3}$. \\ 1. Practicing Architect and Researcher. \\ 2. Professor of Architecture and Urban Theory, The American University In Cairo. \\ 3. Associate Professor of Architecture, Cairo University.
}

\section{Manuscript Info}

.........................

Manuscript History

Received: 23 October 2016

Final Accepted: 21 November 2016

Published: December 2016

Key words:-

Landscape - Streetscape - Xeriscape- Green road-Environmental sustainability-wise water.

\section{Abstract}

This paper discusses the possibility to develop a group of parameters that would help reach an appropriate and water efficient streetscape. The research relies on the principles of Xeriscape as an approach to develop water efficient streetscape guidelines. It also investigates the application of these principles:appropriate planning and design, efficient turf, soil analysis and improvement, adequate plant selection and zoning, efficient system of irrigation and appropriate maintenance; in relation to the requirements of proper streetscape design. A framework for application is reached based on these theoretical backgrounds.

The study then evaluates the validity of this framework by applying it to two case studies in the Cairene context in Egypt which is characterized by a hot arid climate. The outcome of the research gives indicators to the percentage of water efficiency achieved by applying this proposed framework for streetscape design

Copy Right, IJAR, 2016,. All rights reserved.

\section{Introduction:-}

Egypt is a hot arid climate country, with high temperatures, humidity and dusty hot winds which causes an uncomfortable outdoor environment for people. Thus landscape should be integrated more as a way to improve the micro climate of the outdoor built environment. Egypt is also a country facing water crises. With 47,500 $\mathrm{km}^{1}$ of street to plant; which consume -- according to Horticulture Research Institute, 2012 -- around $=\mathbf{1 . 7 1}$ million cubic meters/day, which equals $\mathbf{6 1 5 . 5}$ million cubic meters by year, saving water and improving water management has become a must.

Among these factors, this paper addresses the possibility to reach an appropriate and efficient water streetscape design guideline in hot arid climates. In order to develop this framework, water efficient approaches and streetscape design guidelines are discussed.

\section{Streets and Streetscape:-}

"Street is an element that plays a functional and aesthetic role in the urban environment; it also gives a character to the urban space through its different elements",2.

Adequately planted and efficiently maintained trees are an investment in the city. The streetscape design, hence, becomes an important element to study relevant to the local contexts. Following is a discussion about factors affecting contextual streetscape design.

(MarkazIlTaa’biaWaAlihsaa,) Cairo, Egypt

${ }^{2}$ Moughtin. C, Urban design: street and square. Oxford: Architectural Press 1992, p142 


\section{Streetscape Design Guidelines:-}

To obtain a successful streetscape some factors should be taken into consideration.

The following diagram illustrates those factors and their interrelated relationships.

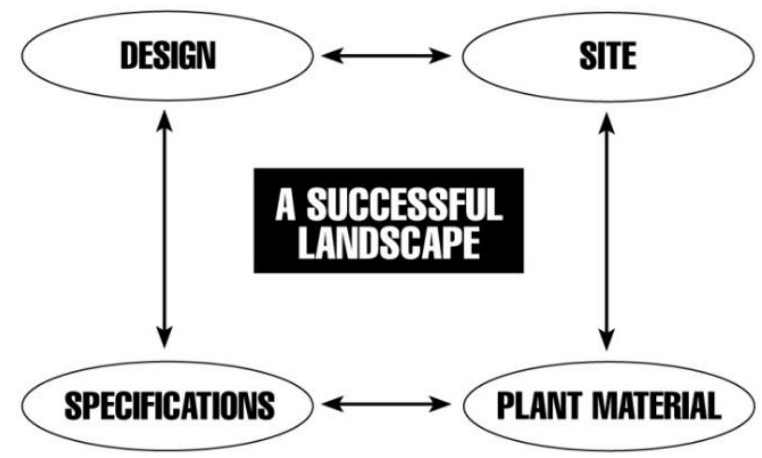

Figure 0-1:- Diagram showing a successful landscape design steps (West, et al 2005)

- Design: an appropriate design to needs and requirements.

- Site: site evaluation and proper preparation.

- Plantation material: adequate plant selection and placement based on contextual conditions.

- Specifications: proper placement and maintenance techniques based on realistic measures.

The above stated aspects all rely on each other. They all need to be done properly so that they do not affect the integrity of the whole project.

\section{A Good Design:-}

A good design must provide a balance between the function and the aesthetic aspects. Aesthetically, most plants are viewed in terms of beauty and comfort they bring to the landscape. They provide visual accent and background, textural interest, color, and seasonal variation. During the design, one should concentrate on evaluating the visual relationships among elements of which the basic principles include unity, harmony, continuity, repetition, accent, balance, scale, proportion, simplicity, and variety. An effort should also be carefully induced to preserve the existing character both from its visual aspects and ecological function. This should also consider the site within its local and regional context to use native plants wherever possible.

Functionally, plantation material plays many roles at the environmental, safety and economic levels such as:

Table 0-1:-Softscape role (researchers)

\section{Environmental level}

- Solar Radiation absorption.

- Preventing pollution.

- Temperature.

- Wind control.

- Reduce noise.

- Soil conservation.

- Gases transformation.

- Radiation absorption.

- Ecosystem support.

\section{Safety level}

- Reduced and more appropriate urban traffic speeds.

- Create safer walking environments.

- Trees planting strips.

- Increased security.

- Reduced road rage.

\section{Economical level}

- Improved business.

- Added value to adjacent homes.

- Longer pavement life.

- Less drainage infrastructure.

- Lower urban air temperatures.

- Time in travel perception

Furthermore, and at the social level, cultural traditions of specific user groups and their habits should provide the base for a unique outcome. 


\section{Proper Site Evaluation and Preparation:-}

Site evaluation should include all the factors that may affect the plants such as the regional and microclimatic conditions of the site, sun or shade requirements, wind pattern, existing vegetation, topography and the special characteristics of site contour, pollution, and soil condition (moisture, texture and type) to allow for enough room for good root system development.

Table 0-2:-Relation between street type and softscape elements (researchers)

\begin{tabular}{|c|c|c|c|c|c|}
\hline \multicolumn{2}{|c|}{ Street Classification due to } & \multirow{2}{*}{$\begin{array}{l}\text { Traffic } \\
\text { capacity }\end{array}$} & \multirow{2}{*}{ Description } & \multirow{2}{*}{$\begin{array}{l}\text { Streetscape main } \\
\text { role }\end{array}$} & \multirow{2}{*}{$\begin{array}{l}\text { Suggested streetscape } \\
\text { element }\end{array}$} \\
\hline Function & Land use & & & & \\
\hline $\begin{array}{l}\text { Highway or } \\
\text { freeway }\end{array}$ & & Very High & $\begin{array}{l}\text { Designed for travel between urban } \\
\text { area with little or no access. }\end{array}$ & $\begin{array}{l}\text { Forming \& } \\
\text { framing visual } \\
\text { walls }\end{array}$ & $\begin{array}{l}\text { Tree available for } \\
\text { screening- bollards- } \\
\text { wall screening } \\
\end{array}$ \\
\hline $\begin{array}{l}\text { Principal or } \\
\text { A Minor } \\
\text { Arterial }\end{array}$ & $\begin{array}{l}\text { Commuter } \\
\text { Street }\end{array}$ & High & $\begin{array}{l}\text { Traverses and connects districts and } \\
\text { cities; primary a longer distance route } \\
\text { for all vehicles including limit access. } \\
\text { They are usually designed with long- } \\
\text { distance travel in mind. }\end{array}$ & $\begin{array}{l}\text { Often has a planted } \\
\text { median. Well treed } \\
\text { road aim to } \\
\text { perceive time. }\end{array}$ & $\begin{array}{l}\text { Public art - Varity of } \\
\text { tree since it is a long } \\
\text { distance travel- }\end{array}$ \\
\hline $\begin{array}{l}\text { A/B Minor } \\
\text { Arterials }\end{array}$ & $\begin{array}{l}\text { Commerce } \\
\text { Street }\end{array}$ & Medium & $\begin{array}{l}\text { Street that supports commercial and } \\
\text { higher intensity residential land uses } \\
\text { on a corridor basis. }\end{array}$ & $\begin{array}{l}\text { Organized element } \\
\text { allowing the view } \\
\text { of shops }\end{array}$ & $\begin{array}{l}\text { Street corners- Seating } \\
\text {-Café space - Trash }\end{array}$ \\
\hline $\begin{array}{l}\text { A/B Minor } \\
\text { Arterials, } \\
\text { Collectors, } \\
\text { Locals }\end{array}$ & $\begin{array}{l}\text { Activity Center } \\
\text { Street }\end{array}$ & Medium & $\begin{array}{l}\text { They provide a balance between } \\
\text { access and mobility. Street that } \\
\text { provides access to abutting properties in } \\
\text { activity centers. }\end{array}$ & $\begin{array}{l}\text { Flexible site layout } \\
\text { \& comfortable } \\
\text { outdoor } \\
\text { environment }\end{array}$ & $\begin{array}{l}\text { Special events spaces- } \\
\text { kiosk - planter raised- } \\
\text { planter moveable- café } \\
\text { space. }\end{array}$ \\
\hline $\begin{array}{l}\text { B Minor } \\
\text { Arterials and } \\
\text { Collectors } \\
\end{array}$ & $\begin{array}{l}\text { Community } \\
\text { Connector }\end{array}$ & Medium & $\begin{array}{l}\text { Street that connects neighborhoods with } \\
\text { each other and with commercial } \\
\text { corridors and other parts of the city. }\end{array}$ & $\begin{array}{l}\text { Comfortable, } \\
\text { shady, flexible site } \\
\text { layout }\end{array}$ & $\begin{array}{l}\text { Seating- Street corners- } \\
\text { Tree providing shade }\end{array}$ \\
\hline Collectors & $\begin{array}{l}\text { Neighborhood } \\
\text { Connector }\end{array}$ & Low - Medium & $\begin{array}{l}\text { Street that connects neighborhoods with } \\
\text { each other. }\end{array}$ & $\begin{array}{l}\text { Distinguish design, } \\
\text { safe \& comfortable }\end{array}$ & $\begin{array}{l}\text { Seating- Street corners- } \\
\text { planter raised. }\end{array}$ \\
\hline Collectors & $\begin{array}{l}\text { Industrial } \\
\text { Connector }\end{array}$ & Low - Medium & $\begin{array}{l}\text { Street that connects employment areas to } \\
\text { neighborhoods and truck or commuter } \\
\text { access routes. }\end{array}$ & $\begin{array}{l}\text { Preventing } \\
\text { pollution \& } \\
\text { reducing noise }\end{array}$ & $\begin{array}{l}\text { Trees that can be used } \\
\text { as a buffer and that } \\
\text { have a high capability } \\
\text { to transform gas. }\end{array}$ \\
\hline Locals & Parkway Street & Lowest & $\begin{array}{l}\text { Link between streets; allows access } \\
\text { to garages and parklands }\end{array}$ & Well Shaded & $\begin{array}{l}\text { Trees providing good } \\
\text { shade }\end{array}$ \\
\hline
\end{tabular}

Note: Some streetscape elements are common in all type of streets such as: lighting fixtures- signs- Trash- Utilities.

\section{Plant Material:-}

Matching the appropriate plant to place is key in achieving an adequate environment.

\section{Proper Plant Selection:-}

Plant selection usually depends on being appropriate to the site and to the role the plant is designed for. Appropriate to the site means that the plant must be suited to the light exposure, drainage, soil chemistry (soil type and $\mathrm{pH}$ value), volume, and other factors of the site. In general any street tree should have some special properties such as ${ }^{3}$ :

- Pollution, disease and insects resistant.

- Deep roots and drought tolerant.

- Suitable size for the sidewalk width.

- Enhance and strengthen the architecture and natural environment of the context.

- Ground moisture and wind suitability.

- Longevity.

- Consistent shading in relation to location.

- Minimum maintenance requirements and leaf falls.

On the other hand, the type of street, the adjacent land use and type of users affect design decisions. Therefore, studying each is important. The following table illustrates how streetscape element selection changes according to street type and function.

\footnotetext{
${ }^{3}$ Henry, F.: Trees in Urban Design,1980, p124
} 


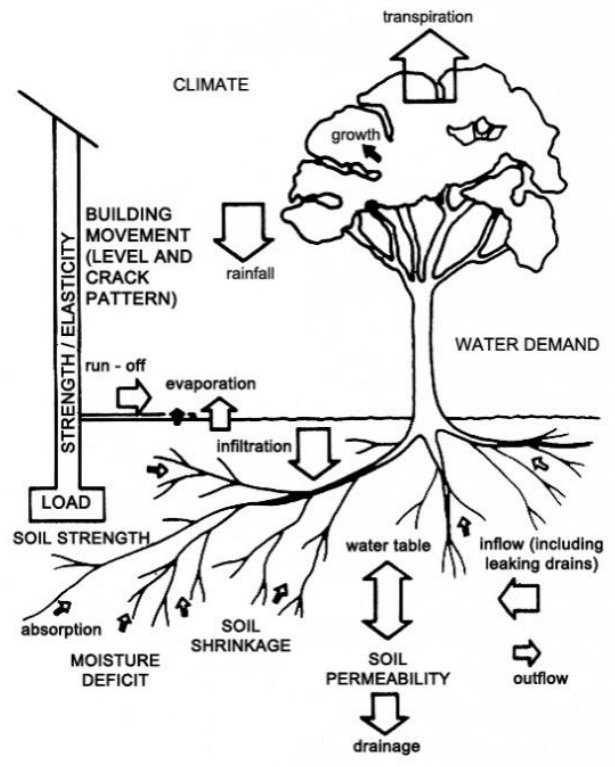

Figure 0-2:- Trees can effect building safety if not properly designed (Brian Clouston, 1981)

\section{Proper Plant Placement:-}

As trees are considered the largest physical objects apart from the buildings in the street urban environment, they usually come in frequent conflict for the available space. The conflict between trees and buildings can take many forms. Above the Obstruction of light and blockage of urban pathways are the most common conflicts above the ground. Underground, roots can block drains and damage pathways and walls of buildings. They can also cause changes in moisture content to shrinkable clay soils resulting in foundation movement and structural damage to buildings.

The many identified problems of street trees could be overcome with care by designers. Some general factors that should be considered to minimize the negative impact of trees on buildings can be summarized as follows ${ }^{4}$ :

- $\quad$ Building foundation depth should be at a convenient level where soil is stable.

- Rooting pattern of tree.

- The pattern of moisture deficit produced by the roots.

- Soil shrinkage and its extent determines the possible foundation movement.

- Soil permeability, affecting extent of moisture movements.

- Climate, and how it affects water input such as water loss from evaporation and transpiration as well as rainfall.

- Water requirements for the tree.

- Behavior of soil under load.

- Behavior of the building if stressed.

- Placing the tree at a convenient distance of the building, in case of shrinkable soil the distance barely exceed the mature tree height, in case of normal soil , the distance is almost $11 / 3$ the mature tree height.

- Drainages pipes should be covered with concrete, a depth of $15 \mathrm{~cm}$ min.

- Sewer should be placed 2-3m under the root main range of the tree.

Street trees placement are controlled by guidelines and regulations in many countries, states and cities. They organize trees locations, relations with other streetscape elements in order to provide safe environments for all users.

In Egypt, the streetscape manual organizes those relations as follows ${ }^{5}$ :-

Table 0-3:- Appropriated from Egyptian streetscape manual regulations (researchers)

\begin{tabular}{|l|l|l|}
\hline Distance between & Egyptian code & \\
\hline Location & \\
\hline
\end{tabular}

${ }^{4}$ Brian Clouston, K. S. (1981): Trees in Towns, (Maintenance and Management), London: The Architectural Press وزارة الأسكان و المر افق و التنمية العمر انية،2006، " دليل معايير تتسيق عناصر الطريق"، المركز القومي لبحوث الأسكان و البناء5 


\begin{tabular}{|c|c|c|}
\hline Trees centers & $\begin{array}{l}\text { Small trees }=4.5 \mathrm{~m} \\
\text { Big trees }=7.5 \mathrm{~m} \\
\text { Tree }(\mathrm{h}<12)=11 \mathrm{~m}\end{array}$ & 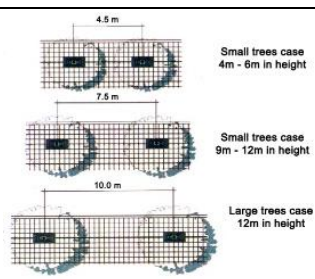 \\
\hline Trees and edge of sidewalk & $\begin{array}{l}\text { Small trees }=60 \mathrm{~cm} \\
\text { Big trees }=90 \mathrm{~cm}\end{array}$ & Focm Large treas case \\
\hline Intersections & Min $11 \mathrm{~m}$ or sight triangle & \\
\hline Trees and lighting fixtures & $6 \mathrm{~m}$ & : \\
\hline Trees and buildings & $\begin{array}{l}60 \mathrm{~cm} \text { between the building } \& \\
\text { smallest tree crown radius }\end{array}$ & \\
\hline $\begin{array}{l}\text { Tree crown flutter } \\
\text { starting height }\end{array}$ & $2.5 \mathrm{~m}$ & \\
\hline \multicolumn{3}{|l|}{ Tree size } \\
\hline & \multicolumn{2}{|l|}{ Depending on sidewalk width } \\
\hline \multicolumn{3}{|l|}{ Tree selection } \\
\hline Special consideration & \multicolumn{2}{|l|}{ Consider different tree size } \\
\hline Plants list & \multicolumn{2}{|c|}{ A general street plant list exists in the code } \\
\hline
\end{tabular}

One may notice that some important requirements are missing in the Egyptian code such as:

- Considering water requirements in design.

- Responding to street use and users on the street.

- Enhancing a special character for each district.

- Protection of existing trees in the site.

- A recommended tree list to follow climate zoning.

One can conclude that choosing the proper tree placement requires not only the knowledge of the space needed by the tree and its properties, but aspects of street usage, district / zone character as well as the country specific regulations.

Proper Installation and Maintenance Techniques

The preparation, application and maintenance should comply with the needs of the plants, the introduced design, potential aesthetic impact conditions and the site. 
The cost of long term maintenance must be weighed against planting costs. In general, plants cost less than hardscape and if properly chosen and maintained the overall cost is less.

\section{Concluding Remark:-}

Streetscape has a very remarkable role in enhancing and creating a more favorable and healthy urban space. When facing a water crises, obtaining favorable streetscape design through water efficient ways is key to a successful softscape. Studying how to apply the basic principles of Xeriscape (which is one of the water efficient landscape concepts) in local contexts, is key in this research to develop the appropriate and efficient framework for applying streetscape design.

\section{Xeriscape:-}

Xeriscaping refers to a water efficient landscape approach leading to "quality landscaping that conserves water and protects the environment". ${ }^{6}$ The word is derived from both the Greek word "xeros, "which means "dry," and scape which means "vista". It is pronounced "zeri-scape". Xeriscape. In some areas, terms such as water-conserving landscapes, drought-tolerant landscaping, zeroscaping, and smart scaping are used instead.

Although studies have shown that xeriscape, can reduce significantly the amount of used water (50 percent or more) and also reduce the cost of maintenance (to 30 percent) following adequate planning principles ${ }^{7}$, water conservation isn't the only benefit of Xeriscape; it offers many others on economic and environmental for example lowering bills, decreasing energy use, reducing maintenance cost and conserving natural context ${ }^{8}$ :

Hence, if designed properly, Xeriscape can be lush, colorful and easy to care for.

\section{Xeriscape Principals:-}

The Xeriscape concept can be summarized in seven principles:

- Adequate planning and proper design.

- Analysis of the soil and its improvement.

- Practical turf.

- Plant selection relevant to site and context.

- An effective and efficient irrigation system.

- Proper and efficient mulch use.

- Adequate maintenance.

In order to apply an efficient design, the sequence of addressing the above outlined principles is crucial to realize a real xeriscape.

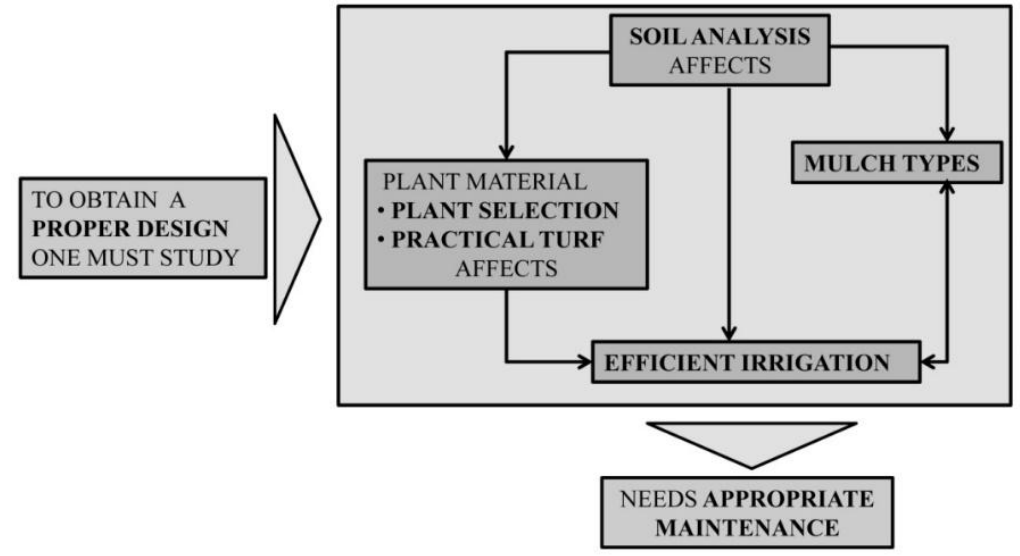

Figure 0-1:- Relation between Xeriscape principals (researcher)

\footnotetext{
${ }^{6}$ Environmental Protection Agency, "Water - efficient Landscaping: preventing, pollution \& using resource wisely", Washington

${ }^{7}$ Eastbay municipal utility district, 2008, Water Smart_Guide Landscape Water Use Efficiency EBMUD, California.

${ }^{8}$ U.S Environmental protection Agency, "Water - efficient Landscaping: preventing, pollution \& using resource wisely",N.W. Washington, D.C
} 
As shown in the previous figure, the first step is the design. Through the design process one must study site properties including soil analysis and decide which type of plant and turf is to be used that leads to the most efficient irrigation system. The type of mulch used must be defined depending on the type of soil and the irrigation system. At the end, an appropriate maintenance of the soil, plant material and irrigation system ensure the continuation of a water efficient design.

\section{Adequate planning and proper design:-}

Xeriscape starts with the design process because it requires gathering information; asking questions about owner needs and site potentials and capabilities. The difference between a traditional landscape design and xeriscape is that xeriscape acknowledges water conservation and natural ecological processes as key players. Once the plan is implemented, its success will be determined by whether the design meets the goals, how suitable it is to the site and local weather, soil, and environmental conditions, how plants perform and how much water, materials (resources), and energy are required to maintain it. Defining activities and grouping the ones that overlap to efficiently utilize the same space is better.

When and how the design plan translates into reality depends on time, energy, and money. In general, the first activities undertaken should be those that cause the most disruption or damage.

\section{Analysis of the soil and its improvement:-}

All higher plants require the following factors for growth, light, heat, water, oxygen, nutrients, and mechanical support. Except for light, all plants' growth requirements (heat, water, oxygen, nutrients) are supplied by soil or a soil substitute; however, they must be supplied in the proper combination for best plant growth. Thus soil analysis is necessary to obtain a successful landscape.

After finishing all soil analysis, choosing the more suitable way to improve it follows:-

Paths to soil improvement:

Improving soil's conditions could be realized through many paths, such as: ${ }^{9}$

1. Adding amendments: Amendments are used to improve soil aeration and drainage of fine texture or compact soil, or they are used to increase the water and nutrient holding capacities of coarse soil. Amendments are divided into two types: organic and non-organic.

2. By aeration: Aeration introduces air into compacted or tight soil by poking holes several inches into it or moving soil cores. It is achieved by breaking up hardpan and soil clods or by coring.

3. Careful soil management: It is another way to deal with difficult soil conditions. For example, monitoring irrigation and using fertilizers and mulch efficiently may be the most practical ways dealing with coarse soil in which plants need frequent irrigation.

4. Selecting plants best suited to the existing soil: It is more practical, less frustrating, and often less expensive to select the appropriate plant for the site rather than changing the site for plant.

\section{Plant selection relevant to site and context:-}

The wider the gap there is between what the plants need and what the site or design allows, the greater the energy required to grow the plants.

In natural ecosystems, plants favor and thrive in one type of environment over another. Thus, the first step is selecting plants for cultivation from environments similar to their landscapes, zoning landscape is the next step.

\section{Plant selection:-}

According to Detweiler, A., ${ }^{10}$ to obtain a successful plant selection many factors should be taken in consideration. Those factors are mainly divided to 3 categories: Site, functions \& quality as follow:

\footnotetext{
${ }^{9}$ Weinstein, G. (1999). Xeriscape Handbook. Colorado: Fulcrum Publishing

${ }^{10}$ Detweiler, A., 2010 Water wise Gardening: Creating Your Own Xeriscape, OSU-Department of Horticulture.
} 


\begin{tabular}{|c|c|}
\hline $\begin{array}{l}\text { Site } \\
\text { Site properties have a big } \\
\text { impact on plant selection } \\
\text { - Microclimates(Wind, } \\
\text { shade, frost pockets, } \\
\text { topography, drainage) } \\
\text { - Annual precipitation } \\
\text { - Soil type }\end{array}$ & $\begin{array}{l}\text { Function } \\
\text { Plant function may } \\
\text { change according to } \\
\text { its properties: } \\
\text { - } \quad \text { shade } \\
\text { - fruit } \\
\text { - fall color } \\
\text { - texture } \\
\text { - flower } \\
\text { - fragrance } \\
\text { - wind break }\end{array}$ \\
\hline
\end{tabular}

\begin{tabular}{|l|}
\hline \multicolumn{1}{|c|}{ Quality } \\
To define plant \\
quality, one has to \\
study: \\
- $\quad$ overall \\
appearance \\
insects, \\
disease, stress \\
resistance \\
branch patterns
\end{tabular}

Furthermore, some others points must be taken in consideration such as:

- Mature plant size in design since plant size changes while growing.

- Non-invasive plants are more preferable.

- Local plants offer "an attractive, hardy, drought resistant, low maintenance landscape while benefiting the environment. Native plants, once established, save time and money by eliminating or significantly reducing the need for fertilizers, pesticides, and water and lawn maintenance equipment" as noted in US EPA's Native Plants Factsheet $^{11}$.

\section{Practical turf areas:-}

A Lawn is uniformly maintained turf grass consisting of thousands of grass plants tightly meshed together, appearing and acting as one. As a unit, it figures prominently in our human habitats. It moderates temperature, control soil erosion, traps dust, reduces glare, and offers human comfort and pleasure. Yet, the widespread use of lawn turf grasses has led to a number of environmental concerns such as the supplementary use of water and fertilizers, pesticides, herbicides, and fungicides to maintain their vigor.

For a practical use of turf some considerations follow ${ }^{12}$ :

- Use decks and patios, as well as alternative ground covers to reduce lawns which are water sensitive.

- Turf areas should be only included in well-defined functions such as recreation or traffic areas.

- Separate grass areas from tree plantations, shrubs and ground covers for watering purposes as they are best watered separately.

- The shape of the turf area is directly related to the difficulty in watering. Odd shapes are difficult to water efficiently.

- Turf areas should be based on function, life style, site conditions, and contextual needs.

\section{An effective and efficient irrigation system:-}

Irrigation is a way of artificially supplying water to plants by means of basins, troughs, pipes, and hoses. Although it enables us to grow plants from over the world, it is difficult to replace the uniformity of distribution and simplicity that natural precipitation provides. It is important to apply the accurate amount of water in the appropriate place and in the right time. ${ }^{13}$

\section{Irrigation design recommendations:-}

To achieve a successfully conservative irrigation systems many studies have been done and based on (Weinstein, $1999)^{14} \&$ (James M. Knopf et al $)^{15}$ some recommendations follow:

\footnotetext{
${ }^{11}$ http://www.epa.gov/greenacres/nativeplants/factsht.html

${ }^{12}$ Design Studios West, Inc. James M. Knopf, ASLA Hydro-Systems KDI, Inc. The Restoration Group, Inc. Gregory

A. White Water-Wise Landscaping Best Practices Manual, A companion guide to Water Efficient Landscape

Design, Colorado Department of Local Affairs, Office of Smart Growth

${ }^{13}$ Eastbay municipal utility district, 2008, Water Smart Guide Landscape Water Use Efficiency EBMUD, California.

${ }^{14}$ Weinstein, G. (1999). Xeriscape Handbook. Colorado: Fulcrum Publishing
} 
- Eliminate planting in areas that difficult to water such as tapering or odd shaped playing beds, slopes, and narrow strips.

- Eliminate planting in areas where plants receive too much water from one direction or are located under overhangs.

- Eliminate or limit cultivating area where reflected heat and light enhance evaporation.

- Modify irrigation methods for slopes, low spots, and other areas where water behaves differently than on flat surfaces.

- Eliminate irrigation overflow onto paved areas and sidewalks by using drip or bubbler systems.

- Coordinate systems so that one area uses the runoff from another.

- Isolate turf grass watering from other plantings.

- Organize irrigation types and times according to sun, wind, elevation, soil characteristics.

- Determine water zones for high, moderate, low, and very low water needs and irrigate according to it.

- Use drip and bubbler emitters for no turf areas where appropriate.

- If water drains quickly (more than 1 inch per hour), use a drip system or cultivate plants adapted to dry soil. If water is draining slowly ( $1 / 4$ inch per hour), it may runoff the surface before it's absorbed. In this case plan for watering in repetitive cycles.

- Plan some irrigation using harvested water or gray water.

- If moving hoses to water, use a timer as a reminder of the time to change or move a hose.

- Irrigate in early morning when wind and evaporation losses are lowest.

Proper and efficient mulch use:-

Mulch is any material applied to the soil surface for protection or improvement of the area covered, including ground cover plants. Mulches are frequently applied around plants to modify the soil environment and enhance plant growth. Mulches are reported to reduce watering demand by 40 to 70 percent $^{16}$ through preventing loss of water from the soil by evaporation. They also suppress weeds, prevent crusting of the soil surface and also add to the beauty of the landscape.

The mulch material may be organic or inorganic ${ }^{17}$ :

Organic mulches may be bark, wood chips, leaves, pine needles, grass clippings or similar material. Soil structure may also be improved using organic mulches. As mulch decays, the material becomes topsoil. Decaying mulch may also add nutrients to the soil. Thus, it needs replenishing to function effectively as mulch.

Inorganic mulches such gravel, pebbles, polyethylene film or woven ground cloth.re considered permanent mulches and rarely need replenishing.

Adequate maintenance:-

The primary goal in landscape maintenance is to preserve the integrity of the design and maintain plant health. Preserving the integrity of a design is a lot easier when the plants perform the way they are supposed to. Successful plant performance is a result of appropriate selections for the design and site. Plant health is easier to sustain while knowing what they need, and what cause stress. Mainly stress are caused by water stress or by insect and diseases

Like all landscape, a water-efficient landscape will require ${ }^{18}$ :

- Regular proper mowing.

- Proper fertilizing, proper pruning.

- Properly timed pest control.

- Avoid mechanical damage.

- Periodic checks of irrigation system.

With the maturity of the landscape with efficient water systems, the maintenance will become less.

\section{Towards A More Appropriate \&Water Efficient Streetscape Design List}

This check/evaluation list applied on the following case studies can be used to evaluate existing streetscape or as a check list for a new streetscape design. The methodology applied provides an understanding of how the check list was conducted

${ }^{15}$ Design Studios West, Inc. James M. Knopf, ASLA HydroSystems KDI, Inc. The Restoration Group, Inc.Gregory

A. White WaterWise Landscaping Best Practices Manual,A companion guide to Water Efficient Landscape Design, Colorado Department of Local Affairs, Office of Smart Growth

${ }^{16}$ Eastbay municipal utility district, 2008, Water Smart Guide Landscape Water Use Efficiency EBMUD, California.

${ }^{17}$ Ibid.

${ }^{18}$ Eastbay municipal utility district, 2008, Water Smart Guide Landscape Water Use Efficiency EBMUD, California. 
and organized in order to obtain criteria that could be helpful for achieving appropriate and water efficient streetscape. It starts with information gathering regarding all factors that could affect design decisions followed with a criteria table which combines both appropriate streetscape guidelines studies and xeriscape design guidelines studies.

The design criteria are divided into 5 sections:

- $\quad$ Plant selection \& placement section.

- Water efficient turf section.

- Irrigation section.

- Practical section.

- Maintenance section.

The validity of the design is examined by evaluating how much each criterion is achieved; this is represented by the percentages shown in the criteria table.

Each criterion is evaluated per percentages of achievement. Percentages are divided into 4 categories $0,25,50$ and 75 percent. Since a $100 \%$ achievement isn't practically possible, the validity of the design will be examined by passing at least $50 \%$ in issues concerning quality of streetscape and $75 \%$ in issues concerning water efficiency.

Due to the fact that most criteria outlined cannot be numerically evaluated with accuracy; results obtained should be examined by experts. In this research, the experts selected were the general director of plantation affairs at the new cities development association and agriculture engineer at the plantation affairs at the new cities development association.

\section{Case Study:-}

In order to discuss practical ways to evaluate streetscape and water efficiency, the application of the above reached framework is conducted on 2 case studies. The following briefly notes the practical study constraints, case selection and methodology, applying the evaluation list on each case than comparing between them. The comparison helps define the strengths and weaknesses of each point in the list and thus finding ways to improve them.

\section{Practical study constraints:-}

To obtain an efficient evaluation some conditions must be available in the selected cases and are listed as follows:

a. streetscape operation must be completed; the credibility of the water consumption is only real if the streetscape is completed,

b. the presence of middle isle, which allows for the existence of an available amount of landscape,

c. a variety in side Street usage: since this type of street should represent the majority of the streetscape profiles, and,

d. different hierarchy: as this gives a wider range of study and evaluation.

\section{Case study selection:-}

The cases under study in the paper are:

- Dahshour connection, 6 October City. (The road is connecting between Juhayna square and Wahat road).

- 26 July Axe extension, 6 October City. (Situated in 6 October city, the part starting from Juhayna Square till MUST University).

\section{Methodology of the practical Study:}

The practical study is divided into 3 stages:

- Information gathering

- Evaluations and comparison

- Observations and conclusions

Information gathering:-

Through monitoring, photographing, observation of the street and by filling the monitoring previous exemplar all needed information for evaluations process was obtained.

Table 0-1:- Cases Information gathering.

\begin{tabular}{|l|l|l|}
\hline & Case 1: Dahshour connection, 6 October & Case 2: 26 July Axe extension, 6 October City. \\
\hline Type of street & Collector & Major \\
\hline Varieties of softscape elements & Few Elements & Moderate elements \\
\hline Irrigation system & sprinklers & Hose \\
\hline Distinguish character & none & none \\
\hline Softscape elements & $\begin{array}{l}\text { Pasplum - Hibiscus -FicusNitida- } \\
\text { DelonixRegia- Phoenix Dactylifera }\end{array}$ & $\begin{array}{l}\text { Pasplum - Hibiscus -FicusNitida- chorisia_speciosa- Ph } \\
\text { Dactylifera- Washingtuniafilifera- Yucca elephantipes }\end{array}$ \\
\hline
\end{tabular}




\section{Evaluation:-}

After monitoring the existing conditions and streetscape evaluating it appropriation and water efficiency follows:

Table 0-2:-Cases evaluation table.

\begin{tabular}{|c|c|c|c|c|c|c|c|c|c|c|}
\hline \multicolumn{11}{|c|}{$\begin{array}{l}\text { PLANT SELECTION AND PLACEMENT } \\
\text { PLANT SUITABLE FOR STREET }\end{array}$} \\
\hline \multirow{2}{*}{\multicolumn{3}{|c|}{ Criteria }} & \multicolumn{3}{|c|}{$\begin{array}{l}\text { Case 1: Dahshour } \\
\text { connection, } 6 \text { October } \\
\text { City. }\end{array}$} & \multicolumn{5}{|c|}{$\begin{array}{l}\text { Case 2: } 26 \text { July Axe extension, } \\
6 \text { October City. }\end{array}$} \\
\hline & & & 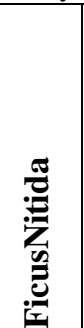 & 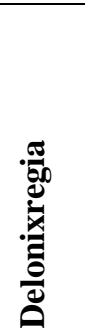 & 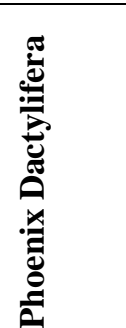 & 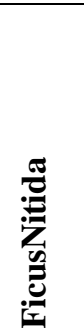 & 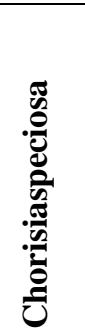 & 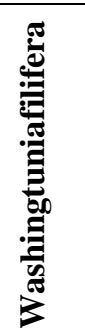 & 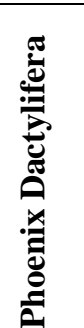 & 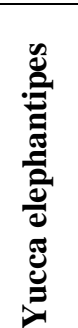 \\
\hline \multicolumn{3}{|c|}{ Pollution, disease and insects resistant. } & $75 \%$ & $75 \%$ & $50 \%$ & $75 \%$ & $75 \%$ & $75 \%$ & $50 \%$ & $75 \%$ \\
\hline \multicolumn{3}{|c|}{ Deep roots and drought tolerant } & $50 \%$ & $75 \%$ & $75 \%$ & $50 \%$ & $75 \%$ & $75 \%$ & $75 \%$ & $75 \%$ \\
\hline \multicolumn{3}{|c|}{ Suitable size for the sidewalk width. } & $75 \%$ & $75 \%$ & $75 \%$ & $75 \%$ & $50 \%$ & $75 \%$ & $75 \%$ & $75 \%$ \\
\hline \multicolumn{3}{|c|}{$\begin{array}{l}\text { Enhance and strengthen the architecture } \\
\text { and natural environment of the context. }\end{array}$} & $50 \%$ & $50 \%$ & $50 \%$ & $50 \%$ & $50 \%$ & $50 \%$ & $50 \%$ & $50 \%$ \\
\hline \multicolumn{3}{|c|}{ Suitability to environmental conditions } & $75 \%$ & $75 \%$ & $75 \%$ & $75 \%$ & $75 \%$ & $75 \%$ & $75 \%$ & $75 \%$ \\
\hline \multicolumn{3}{|c|}{ Shading consistent with location } & $75 \%$ & $50 \%$ & $25 \%$ & $75 \%$ & $50 \%$ & & $25 \%$ & $50 \%$ \\
\hline \multicolumn{3}{|c|}{ Minimum maintenance requirements } & $75 \%$ & $50 \%$ & $50 \%$ & $75 \%$ & $50 \%$ & $75 \%$ & $50 \%$ & $50 \%$ \\
\hline \multicolumn{3}{|c|}{\begin{tabular}{l|l} 
& Minimal leaf fall in autumn \\
\end{tabular}} & $75 \%$ & $50 \%$ & $75 \%$ & $75 \%$ & $25 \%$ & $75 \%$ & $75 \%$ & $75 \%$ \\
\hline \multicolumn{3}{|c|}{ Total achievement percentage } & \multicolumn{3}{|c|}{$63 \%$} & \multicolumn{5}{|l|}{$64 \%$} \\
\hline \multicolumn{11}{|c|}{ PLANT PLACEMENT DUE TO EGYPT STREETSCAPE MANUAL } \\
\hline \multicolumn{11}{|c|}{ Middle Isle } \\
\hline \multicolumn{2}{|c|}{ Criteria } & \multicolumn{4}{|c|}{$\begin{array}{l}\text { Case 1: Dahshour } \\
\text { connection, } 6 \text { October City. }\end{array}$} & \multicolumn{5}{|c|}{$\begin{array}{l}\text { Case 2: } 26 \text { July Axis extension, } \\
6 \text { October City. }\end{array}$} \\
\hline \multicolumn{2}{|c|}{ Distance between } & \multicolumn{4}{|c|}{$75 \%$} & \multicolumn{5}{|c|}{$75 \%$} \\
\hline Trees & center and edge of sidewalk & \multicolumn{4}{|l|}{$75 \%$} & \multicolumn{5}{|l|}{$75 \%$} \\
\hline Inters & ctions & $50 \%$ & & & & $75 \%$ & & & & \\
\hline Trees & centers and lighting fixtures & $\begin{array}{c}---- \\
-\end{array}$ & & & & $50 \%$ & & & & \\
\hline Trees & and buildings & ---- & & & & ---- & & & & \\
\hline Tree $\mathrm{c}$ & rown flutter starting height & $0 \%$ & & & & $50 \%$ & & & & \\
\hline Siden & & & & & & & & & & \\
\hline Criter & & Case 1 & Dahsh & our & Citv & Case & $2: 26$ & dly Ax & s exter & sion, \\
\hline$\frac{\text { Distal }}{\text { Trees }}$ & $\frac{\text { ce between }}{\text { centers }}$ & $0 \%$ & & Uctobs & cily. & $\frac{600}{50 \%}$ & ober $\mathrm{C}$ & & & \\
\hline Trees & enter and edge of sidewalk & $75 \%$ & & & & $75 \%$ & & & & \\
\hline Inters & ctions & --- & & & & ---- & & & & \\
\hline Trees & centers and lighting fixtures & $0 \%$ & & & & $25 \%$ & & & & \\
\hline Trees & and buildings & $75 \%$ & & & & $75 \%$ & & & & \\
\hline Tree & rown flutter starting height & $0 \%$ & & & & $0 \%$ & & & & \\
\hline Total & chievement percentage & $38 \%$ & & & & $68 \%$ & & & & \\
\hline WAT & R EFFICIENT PLANT SELE & $\overline{\mathrm{ON}} \mathrm{AI}$ & $\overline{\mathrm{PLA}}$ & $\overline{\mathrm{CEMH}}$ & & & & & & \\
\hline Criter & & $\begin{array}{l}\text { Case } 1 \\
\text { connec }\end{array}$ & $\begin{array}{l}\text { Dahsh } \\
\text { ion, } 6\end{array}$ & $\begin{array}{l}\text { our } \\
\text { Octob }\end{array}$ & City. & $\begin{array}{l}\text { Case } \\
6 \mathrm{Oc}\end{array}$ & $\begin{array}{l}2: 26 \\
\text { ober C }\end{array}$ & $\begin{array}{l}\text { dy } \mathrm{Ax} \\
\text { ty }\end{array}$ & s exter & sion, \\
\hline Wate & zoning due to water needs & $25 \%$ & & & & $25 \%$ & & & & \\
\hline Suital & le for soil type & $75 \%$ & & & & $75 \%$ & & & & \\
\hline Apprs & priate to climate & $50 \%$ & & & & $75 \%$ & & & & \\
\hline Elimi & $\begin{array}{l}\text { ate planting in areas that } \\
\text { lt to water }\end{array}$ & $75 \%$ & & & & $75 \%$ & & & & \\
\hline
\end{tabular}




\begin{tabular}{|c|c|c|}
\hline Eliminate planting located under overhar & $75 \%$ & $75 \%$ \\
\hline Total achievement percentage & $60 \%$ & $65 \%$ \\
\hline \multicolumn{3}{|l|}{ WATER EFFICIENT TURF } \\
\hline Criteria & $\begin{array}{l}\text { Case 1: Dahshour } \\
\text { connection, } 6 \text { October City. }\end{array}$ & $\begin{array}{l}\text { Case 2: } 26 \text { July Axis extension, } \\
6 \text { October City }\end{array}$ \\
\hline $\begin{array}{l}\text { Reducing the size of water-sensitive } \\
\text { lawns }\end{array}$ & $25 \%$ & $25 \%$ \\
\hline $\begin{array}{l}\text { Plantings of trees, shrubs, ground } \\
\text { covers separately from grass }\end{array}$ & $25 \%$ & $25 \%$ \\
\hline Selecting turf grass, due to the use & $50 \%$ & $50 \%$ \\
\hline $\begin{array}{l}\text { No turf in areas less than } 2.43 \mathrm{~m} \\
\text { wide }\end{array}$ & $75 \%$ & $75 \%$ \\
\hline Total achievement Percentage & $43 \%$ & $43 \%$ \\
\hline \multicolumn{3}{|l|}{ EFFICIENT IRRIGATION SYSTEM } \\
\hline Criteria & $\begin{array}{l}\text { Case 1: Dahshour } \\
\text { connection, } 6 \text { October City. }\end{array}$ & $\begin{array}{l}\text { Case 2: } 26 \text { July Axis extension, } \\
6 \text { October City }\end{array}$ \\
\hline $\begin{array}{l}\text { Coordinate systems so that one area } \\
\text { uses the runoff from another }\end{array}$ & $0 \%$ & $0 \%$ \\
\hline $\begin{array}{l}\text { Isolate turf grass watering from } \\
\text { plantings }\end{array}$ & $0 \%$ & $0 \%$ \\
\hline Using harvested water or gray water & $75 \%$ & $75 \%$ \\
\hline If moving hoses to water, use a timer & $\begin{array}{ll}-- \\
\end{array}$ & $0 \%$ \\
\hline Focus water on plant roots & $25 \%$ & $25 \%$ \\
\hline Total achievement percentage & $50 \%$ & $20 \%$ \\
\hline \multicolumn{3}{|l|}{ PRACTICAL PAREMETERS } \\
\hline Criteria & $\begin{array}{l}\text { Case 1: Dahshour } \\
\text { connection, } 6 \text { October City. }\end{array}$ & $\begin{array}{l}\text { Case 2: } 26 \text { July Axis extension, } \\
6 \text { October City }\end{array}$ \\
\hline Avoid using water to clean driveways pa & $75 \%$ & $75 \%$ \\
\hline Irrigate in early morning & $0 \%$ & $0 \%$ \\
\hline Apply water slowly & $0 \%$ & $0 \%$ \\
\hline Do not rely on automatic timers & $75 \%$ & ---- \\
\hline Total achievement percentage & $37 \%$ & $25 \%$ \\
\hline \multicolumn{3}{|l|}{ MAINTENANCE } \\
\hline \multicolumn{3}{|l|}{ PLANT MAINTENANCE } \\
\hline Criteria & $\begin{array}{l}\text { Case 1: Dahshour } \\
\text { connection, } 6 \text { October City }\end{array}$ & $\begin{array}{l}\text { Case 2: } 26 \text { July Axis extension, } \\
6 \text { October City }\end{array}$ \\
\hline Control weeds & $25 \%$ & $50 \%$ \\
\hline Regular proper mowing & $50 \%$ & $75 \%$ \\
\hline Properly timed pest control & $25 \%$ & $25 \%$ \\
\hline Proper fertilizing & $50 \%$ & $50 \%$ \\
\hline Total achievement percentage & $43 \%$ & $50 \%$ \\
\hline \multicolumn{3}{|l|}{ IRRIGATION SYSTEM } \\
\hline Criteria & $\begin{array}{l}\text { Case 1: Dahshour } \\
\text { connection, } 6 \text { October City }\end{array}$ & $\begin{array}{l}\text { Case 2: } 26 \text { July Axis extension, } \\
6 \text { October City }\end{array}$ \\
\hline Avoid mechanical damage & $50 \%$ & ---- \\
\hline Periodic checks of irrigation system & $50 \%$ & ---- \\
\hline $\begin{array}{l}\text { If using a hose make sure it has a } \\
\text { shut-off nozzle }\end{array}$ & $\begin{array}{l}--- \\
-1\end{array}$ & $50 \%$ \\
\hline Total achievement percentage & $50 \%$ & $50 \%$ \\
\hline $\begin{array}{l}\text { Total achievement percentage for } \\
\text { street criteria }\end{array}$ & $50 \%$ & $58 \%$ \\
\hline $\begin{array}{l}\text { Total achievement percentage for } \\
\text { efficient }\end{array}$ & $48 \%$ & $38 \%$ \\
\hline
\end{tabular}




\section{Observations and Concluding Remarks:-}

After monitoring, analysis and evaluating all softscape elements and watering systems in both cases one may conclude:

- Case 1 achieved $48 \%$ of water efficiency criteria and $50 \%$ of appropriation streets criteria.

- Case 2 percentage of achievements of street criteria is $58 \%$ and for water efficient criteria is $38 \%$ which are very low percentage.

- Case2 elements are more organized due to Egypt streetscape manual than case 1 although the latter is more water efficient.

- Only two types of trees and one type of palm is used in case 1, which indicates that no variation of used elements.

- In both cases, trees selection didn't reflect the important role it could play to improve the environmental conditions; also it didn't consider the adjacent street land use.

- Softscape elements are in a big way suitable for streetscape conditions and resistance to pollution in both cases.

- The elements location subjects' Egyptian code in the middle isle only, elements on sidewalk doesn't.

- Only few water efficiency measurements are done in both cases, thus more are need to be applied.

- More maintenance is needed in both cases.

- Sidewalk in front of private sector has a lot more maintenance than other part of the street plus it has a totally different natural context.

- The streets don't have a specific aesthetic character.

- There isn't any system or gage that monitors the actual water usage during irrigation process the only reference found is based on estimation.

- Irrigation workers have a lack of awareness of water efficiency importance

During the practical study, many weakness point and lack of measurements showed, thus conclusions and suggestions that may lead to a more water efficient softscape follows.

\section{Conclusions and Recommendations:}

This paper aimed to identify a list of parameters for a wise watering and appropriate streetscape. The goal was realized through studying theoretically streetscape requirements and Xeriscape principals and applying it on 2 case studies aiming to evaluate the level of effectiveness of streetscape in Egypt and ways to increase it efficiency.

Many deflections, missing measurements and rules concerning the applications of streetscape water efficiency concept in Egypt appeared through the study. The paper introduced a framework (check and evaluation list) by which one can achieve a more water efficient and appropriate streetscape. Four levels of recommendations are hence noted:

On the design level, one may conclude that: streetscape design should be involved in early stages of planning, so enough space is prevented to this process. Also, a good design should include comfort, simplicity, attraction, low maintenance requirements, water efficiency requirements, connivance to local context and not blocking movement \& a well-studied relation between street trees and buildings.

On the other hand, street trees must have some special properties such as pollution, disease and insects resistant, drought tolerance, etc. Thus it is recommended to improve planning and management procedures to appropriate allocate and use water aiming to make the optimum use of available water. Also, good and frequent maintenance is a necessity for a successful streetscape process even in design and execution phases.

With a proper landscaping design, efficient irrigation system, good soil analysis, appropriate plant selection, a good use of mulches and turf and a periodical maintenance should be considered during design stages to obtain not only beautiful landscapes but also water efficient ones.

At the practical level, conclusions and recommendations are reached through the study cases. Many defections appeared such as water efficiency the leak of awareness of all workers in the streetscape sector. Also, the absence of water monitoring, all actions are depending on a certain assumption. Vegetation used in most Egypt streets are common, more varieties are needed and different climate zone must be considered. It is also recommended to increase the awareness of workers and users about the importance of streetscape and ways of water efficiency. More maintenance of streetscape is required too. 
At the regulation level and after studying Egypt streetscape manual, one may conclude that some adjustments are highly needed to obtain a more water efficient manual. Actually ,most regulations in the Egyptian streetscape manual are concerned only about functional issue, such distance between tree and other streetscape fixture but none is concerned about aesthetic aspects , wise water use or enhancing natural context. Thus it is highly recommended to created more sections concerned about the quality of streetscape considering water usage, architectural context, set rules requiring privates sectors to respect it to obtain a harmonically context and creating more specialized lists for each region in Egypt according to climatologically conditions, soil characteristics and available water resource .

On the public level, which in that case are the street users, which have are remarkable role and impact on the success of the streetscape process. In Egypt, it is highly recommended to increasing people awareness about the importance of wisely use water and way to apply it, the softscape a main role in streetscape; it's benefits on different levels such as environmental, safety, economic levels and how water-efficient landscaping has many benefits beside water conservation; it offers several economic and environmental benefits such as less landscaping labor and maintenance costs as well as minimal water bills from reduced water use.

\section{References:-}

1. Anthony Bradshow, B. H. (1995). Trees in the urban landscape (principles and practice). London: E \& FNSPON.

2. Arnold, H. (1993). Trees in urban design. New York: Van Nostrand Reinhold.

3. Ayyad, S. (1999). Egyptian plants Part 1 Hymns in Nature. Cairo: Akhbar El Youm Press.

4. Clouston, B., \& Stansfield, K. (1981). Trees in Towns (Maintenance and Management). London: The architectural Press.

5. Cooke, I. (2008). Watering Gardening. London: New Holland Publishers.

6. Design Studios West, Inc. James M. Knopf, ASLA Hydro-Systems KDI, Inc. The Restoration Group, Inc. Gregory A. White Water-Wise Landscaping Best Practices Manual, A companion guide to Water Efficient Landscape Design, Colorado Department of Local Affairs, Office of Smart Growth

7. Harris, C., \& Dines, N. (1997). Time-saver Standards for landscape Architecture. Los Angeles, California, USA: McgrawHill Professional.

8. Hitchmough, J., \& Fieldhouse, K. (2004). Plant User Handbook: A Guide to Effective Specifying. Oxford: Blackwell Science Ltd.

9. Jacob, A. B. (1993). Great streets. Cambridge: MIT Press.

10. Keefer, R. F. (2000). Handbook of Soils for Landscape Architects. New York: Oxford University Press.

11. Weinstein, G. (1999). Xeriscape Handbook. Colorado: Fulcrum Publishing.

12. West, D.Tilt, K. Ponder, H. \& Williams, D. (2005). Street Trees: site selection, planting, and maintenance in urban landscape. Retrieved July 28, 2011, from www.aces.edu.

13. Electronic Sources:

14. Air force center for engineering and the environment, 1998, landscape design guide available at : http://www.afcee.af.mil/shared/media/document/AFD-091215-035.pdf[ accessed on 9 August 2012]

15. Burden, D. \& Jackson., G. (2008). 22 Benefits of Urban Street Trees. University of Montana. available on : ebookbrowse.com/22-benefits-of-urban-street-trees-pdf-d366614005, [accessed on 3 December 2011]

16. Black, R. Gilman, E. Knox, G. and Kathleen C. "Mulches for the landscape”, Document ENH103, the Environmental Horticulture Department, Florida Cooperative Extension Service, Institute of Food and Agricultural Sciences, University of Florida. Original publication date March 1992. Revised March 1994. Reviewed October 2003. Available at http://edis.ifas.ufl.edu [accessed 24 September 2012]

17. Eastbay municipal utility district, 2008, Water Smart Guide Landscape Water Use Efficiency EBMUD, California. Available http://www.allianceforwaterefficiency.org/Resource_Center/Library/non_residential/EBMUD/EBMUD_WaterSmart_Guide _Landscape_Water-Use_Efficiency.pdf [accessed on 26 December 2011]

18. Moughtin, C. (2003). Urban design: street and square. Oxford: Architectural Press. available on http://www.4shared.com/get/U9OokdWX/URBAN_DESIGN_STREET_AND_SQUARE.html [accessed on 31 October 2012]

19. U.S Environmental protection Agency, "Water - efficient Landscaping: preventing, pollution \& using resource wisely”,N.W. Washington, D.C (www.epa.gov/WaterSense/docs/water-efficient_landscaping_508.pdf) [accessed on 23 February 2012]

\section{Web sites:-}

1. www.xeriscape.org/xeriscape.html

2. http://www.capmas.gov.eg

3. http://www.allianceforwaterefficiency.org/Landscape_and_Irrigation_Library_Content_Listing.aspx

4. http://www.epa.gov/greenacres/nativeplants/factsht.html. 